\title{
Weight yield factor, chemical composition and energy value in three imported
} shellfish species in Nigeria

${ }^{1}$ Lawal-Are, A. O., ${ }^{2} *$ Moruf, R. O., ${ }^{1}$ Ojeah, F. L., ${ }^{1}$ Taiwo, L. O. and ${ }^{1}$ Aligbeh, O. E.

${ }^{I}$ Department of Marine Sciences, University of Lagos, Akoka, Lagos State, Nigeria

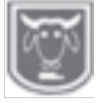

${ }^{2}$ Department of Fisheries and Aquaculture, Bayero University,

Kano, Kano State, Nigeria

Abstract

*Corresponding author: tunjimoruf@gmail.com; +2348022429983

Shellfish is a major component of our global aquatic food supply, which includes the molluscs, crustaceans and echinoderms. The aim of this study was to evaluate the weight yield factor, chemical composition and energy value in three imported shellfish species (Palinurus regius, Sepia officinalis and Farfantepenaeus notialis) in Nigeria. The physical and chemical determinations were in accordance with the official methods. The results showed that all the shellfish species had weight yield factor less than 1, and the weights obtained for the samples showed no statistically significant differences before and after boiling. In raw samples, $S$. officinalis had significant $(p<0.05)$ higher protein and crude fat values of $20.41 \pm 0.63 \mathrm{~g} / 100 \mathrm{~g}$ and $2.67 \pm 0.68 \mathrm{~g} / 100 \mathrm{~g}$ respectively. In boiled samples, high protein levels (15.21-19.22 g/100 g) with no significant difference characterized the overall proximate profile of shellfish species studied herein. In terms of minerals, all investigated elements (calcium, magnesium, potassium, phosphorus and sodium) were generally found at lower levels in boiled samples when compared with the mineral contents of the raw shellfish samples. S. officinalis had the higher total energy value in both raw (344.94 kJ 100/g) and boiled samples (373.96 kJ 100/g). All the species can be considered as food items with interesting dietetic properties due to high contents of proteins, minerals and useful energy values.

Keywords: Cuttlefish, lobster, minerals, proximate, shrimp

\section{Le Facteur de rendement, composition chimique et valeur énergétique de trois espèces de mollusques et crustacés importés au Nigéria}

\section{Résumé}

$\overline{\text { Les mollusques et crustacés sont une composante importante de notre approvisionnement }}$ alimentaire aquatique mondial, qui comprend les mollusques, les crustacés et les échinodermes. L'objectif de cette étude était d'évaluer le facteur de rendement pondération, la composition chimique et la valeur énergétique de trois espèces importées de mollusques et crustacés (Palinurus regius, Sepia officinalis et Farfantepenaeus notialis) au Nigéria. Les déterminations physiques et chimiques étaient conformes aux méthodes officielles. Les résultats ont montré que toutes les espèces de mollusques et crustacés avaient un facteur de rendement de poids inférieur à 1, et les poids obtenus pour les échantillons n'ont montré aucune différence statistiquement significative avant et après l'ébullition. Dans les échantillons crus, $S$. officinalis avait des valeurs significatives $(p<0,05)$ de protéines et de matières grasses brutes de 20,41 $\pm 0,63 \mathrm{~g} / 100 \mathrm{~g}$ et 2,67 $\pm 0,68 \mathrm{~g} / 100 \mathrm{~g}$ respectivement. Dans les échantillons bouillis, des niveaux élevés de protéines (15,21-19,22 g/100 g) sans différence significative ont caractérisé le profil proximate global des espèces de mollusques et crustacés étudiées dans le présente. En ce qui concerne les minéraux, tous les éléments étudiés (calcium, magnésium, potassium, phosphore et sodium) ont généralement été trouvés 
à des niveaux inférieurs dans les échantillons bouillis par rapport au contenu minéral des échantillons de mollusques et crustacés crus. S. officinalis avait la valeur énergétique totale la plus élevée dans les échantillons bruts (344,94 kJ 100/g) et bouillis (373,96 kJ 100/g). Toutes les espèces peuvent être considérées comme des aliments aux propriétés diététiques intéressantes en raison de la teneur élevée en protéines, minéraux et valeurs énergétiques utiles.

Mots-clés: Seiche, homard, minéraux, proximate, crevettes

\section{Introduction}

Nigeria is the fourth largest importer of fish in the world, where the country's top suppliers are the United States and Chile, but fish is also sourced from Europe, Asia, and a few African countries, including Mauritania, Algeria, and Mauritius (Daniels et al., 2016). Meanwhile, the shellfish industry offers great potential to the country in terms of food provision, increasing the income of small-scale fishermen faced with dwindling catches, as well as providing livelihood for people in coastal areas (Norhana et al., 2011; Moruf, 2020). It is a valuable sub-sector of the fisheries sector, with potentials for local production and export of shellfish products. Shellfish is a major component of our global aquatic food supply, which includes the molluscs, crustaceans and echinoderms (Moruf and Adekoya, 2018). Worldwide shellfish imports have increased steadily over the past 20 years, with over 300,000 tons of products in 2013 (Dima et al., 2016). However, despite the high acceptability of shellfish products, the exploitation of this resource in Nigeria is still lagging behind due to lack of scientific and technical information for optimum industrial processing. Economically important shellfish such as shrimp, prawn, crayfish, lobster and crab constitute one of the major sources of nutritious food for human, providing an important amount of dietary protein and lipid diet in many countries (Lawal-Are et al., 2018a). Several products related and individual factors can define the quality of a shellfish. Reported commonly used product related factors are: product safety, the nutritional content, freshness and the physical attributes of the fish product (Grunert et al., 2012; Moruf et al., 2020). According to Grunert et al. (2012), quality is a factor strongly related to the raw material itself but also individual factors such as the perceived image and trust in the end product, which influences food choice in general. Nigerians have started using imported marine lobster (Palinurus regius), cuttlefish (Sepia officinalis) and shrimp species (Farfantepenaeus notialis) as commercial meats, though the utilization is yet limited with a little scientific information about the nutritional status of these shellfish species. Thus, the aim of this study was to evaluate the weight yield, chemical composition, and energy value before and after the cooking of these three imported shellfish species ( $P$. regius, $S$. officinalis and $F$. notialis), in order to provide useful nutritional information to seafood consumers in Nigeria.

\section{Sample collection}

Samples of three different imported shellfish species ( $P$. regius, $S$. officinalis and $F$. notialis) were obtained from Ajeloro Fish Market, a popular ice fish sales point in Lagos. Nine samples of each organism were placed in small sterile polyethylene plastic bags in an icebox and transported to the laboratory. The soft tissues were extracted from the shellfish and thoroughly washed with distilled water. The samples were then separated into two parts, one part was analyzed raw and the second part was boiled in water for 20 minutes until the pieces were cooked and tender. The 


\section{Lawal-Are, Moruf, Ojeah, Taiwo and Aligbeh}

processing method followed the procedures described by Lawal-Are et al. (2018b) in the preparation of molluses for table consumption in Nigeria.

\section{Analytical procedures}

The weight yields were determined in a single experiment. The mass ( $\mathrm{g}$ ) before and 1 hour after cooking was determined with a semi-analytical balance. The weight yield factor was calculated dividing the weight of the freshly cooked sample at room temperature by its weight before cooking sample (de Carvalho et al., 2018).

Samples were ground in an analytical micro-mill, and sieved in 20 mesh sieves. Then, the samples were characterized regarding the contents of moisture, lipids, proteins, and ashes according to AOAC (2006).

Total carbohydrates were calculated by difference, i.e., $100-$ (moisture $\%+$ ash $\%$ + lipids $\%+$ proteins $\%+$ fibers $\%$ ). The energy value of the samples was calculated by using the specific Atwater energy factors to obtain $\mathrm{kcal} / 100 \mathrm{~g}$. The energy values in kilojoules were calculated directly from kilocalories by using the conversion factor $4.184 \mathrm{~kJ} x$ kcal (Merrill and Watt, 1955). For the mineral determination, the samples were digested in $\mathrm{HNO}_{3} / \mathrm{HCl}$, while some metal parameters namely calcium, magnesium, potassium, phosphorus and sodium were measured by a Varian Spectra
Atomic absorption spectrophotometer (AAS), Buck Scientific 210 GVP model following the procedure reported by Santoso et al. (2006).

\section{Statistical analysis}

Mean and standard error were derived from data obtained and subjected to analysis of variance (ANOVA) using Microsoft Excel and STAT 7.0 statistical package. Duncan Multiple Range Test (DMRT) was used to sort out the differences in the means at significance level of $95 \%$.

\section{Results and discussion \\ Weight yield of the soft tissue of imported shellfish species}

The results obtained for the weight yields of the sampled shellfish species are shown in Table 1. The weights obtained for the samples ( $P$. regius, $S$. officinalis and $F$. notialis) showed no statistically significant differences before and after boiling. However, they generally have a low weight yield factor $(<1)$. The results obtained were comparable to the values of $0.83 \pm 0.02$ observed for silver carp fish (Ojagh et al., 2013) and $0.80 \pm 0.01$ for Chicken Nuggets (de Carvalho et al., 2018). According to Biandolino et al. (2018), the percent meat yield of a shellfish is a good commercial quality indicator varies seasonally and geographically, depending on food availability and the timing of the gametogenic cycle.

Table 1: Weight yield of three imported shellfish species in Nigeria

\begin{tabular}{llll}
\hline Species & $\begin{array}{l}\text { Weight before } \\
\text { cooking }(\mathrm{g})\end{array}$ & $\begin{array}{l}\text { Weight after } \\
\text { cooking }(\mathrm{g})\end{array}$ & Weight yield factor \\
\hline Palinurus regius & $97.80 \pm 0.05^{\mathrm{a}}$ & $89.98 \pm 0.05^{\mathrm{a}}$ & $0.92 \pm 0.01$ \\
Sepia officinalis & $1228.50 \pm 0.31^{\mathrm{a}}$ & $1089.92 \pm 0.11^{\mathrm{a}}$ & $0.89 \pm 0.05$ \\
Farfantepenaeus notialis & $21.33 \pm 0.12^{\mathrm{a}}$ & $19.25 \pm 0.08^{\mathrm{a}}$ & $0.90 \pm 0.01$ \\
\hline
\end{tabular}

Key: Mean \pm standard deviation $(n=27)$. Means followed by different letters in the same column differ significantly $(\mathrm{p}<0.05)$.

\section{Proximate composition of the soft tissue of imported shellfish species}

The proximate compositions of raw and boiled imported shellfish species are shown in Tables 1 and 2, respectively. As expected, the main component of all studied species is the moisture, whose content indicates flesh freshness. In raw samples, S. officinalis had significant $(\mathrm{p}<0.05)$ highest protein and crude fat values of $20.41 \pm 0.63 \mathrm{~g} / 100 \mathrm{~g}$ and 


\section{Weight yield factor, chemical composition and energy value in three imported shellfish species}

$2.67 \pm 0.68 \mathrm{~g} / 100 \mathrm{~g}$ respectively. Generally, all the species under study represent a good source of protein considering the WHO Daily Value (DV) recommendation of $0.80 \mathrm{~g} / \mathrm{kg} /$ day (Biandolino et al., 2019). Crude fiber with the mean value of $6.31 \pm 0.86$ was found in $P$. regius while below detection level in both $S$. officinalis and $F$. notialis. The highest ash content, which indicates the amount of inorganic compounds in the tissues of shellfish, was found significant in $P$. regius $(6.31 \pm 0.86$ $\mathrm{g} / 100 \mathrm{~g})$. Non-significantly highest $(\mathrm{p}<0.05)$ carbohydrate content was noted in F. notialis $(6.24 \pm 1.27 \mathrm{~g} / 100 \mathrm{~g})$. Protein contents in the imported shellfish samples were comparable to that found in two edible crabs of Lagos coast (Moruf and LawalAre, 2019).

In boiled samples, high protein levels (15.21-19.22 g/100 g) with no significant differences characterized the overall proximate profile of shellfish species studied herein. However, the total lipid amount, exhibited differences among the species, with the highest value determined in $S$. officinalis $(2.75 \pm 0.01 \mathrm{~g} / 100 \mathrm{~g})$, significantly different from the similar crude fat values of $P$. regius $(0.74 \pm 0.06$ $\mathrm{g} / 100 \mathrm{~g})$ and F. notialis $(0.68 \pm 0.12 \mathrm{~g} / 100 \mathrm{~g})$. According to Zhukova (2014), lipids exert important biological functions as energy storage compounds, structural components of the cell membranes and as signalling molecules. Lipid contents in species studied herein were lower than the value of $4.09 \pm 1.42 \mathrm{~g} / 100 \mathrm{~g}$ reported for boiled cuttlefish (Lawal-Are et al., 2018b), but agreed well with those reported for Callinectes amnicola flesh from Badagry Lagoon (2.12 $\pm 0.94 \mathrm{~g} / 100 \mathrm{~g})$, Lagos Lagoon $(1.78 \pm 0.43 \mathrm{~g} / 100 \mathrm{~g})$ and Epe Lagoon $(2.05 \pm 0.44 \mathrm{~g} / 100 \mathrm{~g})$ (Moruf et al., 2019). Under this present study, crude fibre of the boiled samples were below detection level while total ash and carbohydrate contents displayed non-significant differences among the imported shellfish species.

Table 2: Proximate composition of raw flesh of three imported shellfish species in Nigeria

\begin{tabular}{llll}
\hline Parameters $(\mathrm{g} / 100 \mathrm{~g})$ & Sepia officinalis & Palinurus regius & Farfantepenaeus notialis $^{\mathrm{a}}$ \\
\hline \multirow{2}{*}{ Moisture } & $71.14 \pm 1.1^{\mathrm{a}}$ & $72.45 \pm 0.56^{\mathrm{a}}$ & $73.94 \pm 1.66^{\mathrm{a}}$ \\
& $(69.21-73.01)$ & $(71.40-73.33)$ & $(70.80-76.47)$ \\
Protein & $20.41 \pm 0.63^{\mathrm{a}}$ & $14.45 \pm 0.51^{\mathrm{b}}$ & $14.93 \pm 1.35^{\mathrm{b}}$ \\
& $(19.15-21.11)$ & $(13.62-15.38)$ & $(12.52-17.2)$ \\
Crude Fat & $2.67 \pm 0.68^{\mathrm{a}}$ & $0.85 \pm 0.12^{\mathrm{b}}$ & $1.98 \pm 0.06^{\mathrm{c}}$ \\
& $(1.31-3.4)$ & $(0.73-1.08)$ & $(1.87-2.08)$ \\
Crude Fibre & $\mathrm{BDL}$ & $2.20 \pm 0.21$ & BDL \\
& $1.79 \pm 0.34^{\mathrm{a}}$ & $(1.80-2.50)$ & $2.91 \pm 0.06^{\mathrm{c}}$ \\
Total Ash & $(1.11-2.15)$ & $6.31 \pm 0.86^{\mathrm{b}}$ & $(2.80-3.01)$ \\
& $3.99 \pm 0.34^{\mathrm{a}}$ & $(4.72-7.68)$ & $6.24 \pm 1.27^{\mathrm{a}}$ \\
Carbohydrate & $(3.31-4.38)$ & $3.74 \pm 0.55^{\mathrm{a}}$ & $(3.78-8.03)$ \\
\hline
\end{tabular}

Keys: BDL; Below detection level, Mean \pm SE (Range), Means followed by different letters in the same column differ significantly $(\mathrm{p}<0.05)$

Table 3: Proximate composition of boiled flesh of three imported shellfish species in Nigeria

\begin{tabular}{cccc}
\hline Parameters $(\mathrm{g} / 100 \mathrm{~g})$ & Sepia officinalis & Palinurus regius & Farfantepenaeus notialis \\
\hline Moisture & $67.98 \pm 0.67^{\mathrm{a}}$ & $71.87 \pm 1.31^{\mathrm{a}}$ & $72.87 \pm 1.76^{\mathrm{a}}$ \\
& $(66.89-69.19)$ & $(69.58-74.13)$ & $(71.06-76.38)$ \\
Protein & $17.61 \pm 0.34^{\mathrm{a}}$ & $17.59 \pm 1.22^{\mathrm{a}}$ & $17.35 \pm 0.9^{\mathrm{a}}$ \\
& $(17.25-18.30)$ & $(15.21-19.22)$ & $(16.18-19.11)$ \\
Crude Fat & $2.75 \pm 0.01^{\mathrm{a}}$ & $0.74 \pm 0.06^{\mathrm{b}}$ & $0.68 \pm 0.12^{\mathrm{b}}$ \\
Crude Fiber & $(2.73-2.78)$ & $(0.63-0.84)$ & $(0.56-0.91)$ \\
& $\mathrm{BDL}$ & $\mathrm{BDL}$ & $\mathrm{BDL}$ \\
Total Ash & $2.86 \pm 0.34^{\mathrm{a}}$ & $3.24 \pm 0.39^{\mathrm{a}}$ & $2.53 \pm 0.39^{\mathrm{a}}$ \\
& $(2.18-3.21)$ & $(2.47-3.67)$ & $(1.78-3.12)$ \\
Carbohydrate & $8.8 \pm 0.66^{\mathrm{a}}$ & $6.55 \pm 0.83^{\mathrm{a}}$ & $6.58 \pm 1.63^{\mathrm{a}}$ \\
& $(7.61-9.88)$ & $(5.24-8.10)$ & $(3.41-8.83)$ \\
\hline
\end{tabular}

Keys: BDL; Below detection level, Mean \pm SE (Range), Means followed by different letters in the same column differ significantly $(\mathrm{p}<0.05)$ 


\section{Lawal-Are, Moruf, Ojeah, Taiwo and Aligbeh}

Mineral content in the soft tissue of imported shellfish species

The contents of minerals (calcium, magnesium, potassium, phosphorus and sodium) in raw and boiled soft tissue of the imported shellfish species are shown in Table 3 and Table 4 respectively. In raw samples, significant differences $(p<0.05)$ were found in the distribution of the minerals among the species analyzed; though with the exception of sodium, nonsignificant difference was observed between the content of $P$. regius and $F$. notialis. Calcium and magnesium were predominant in $S$. officinalis with respective mean values of $334.2 \pm 3.99$ and $363.84 \pm 4.22 \mathrm{mg} / 100 \mathrm{~g}$; potassium and sodium were predominant in $P$. regius with respective mean values of $305.43 \pm 27.97$ and $482.15 \pm 2.93 \mathrm{mg} / 100 \mathrm{~g}$; phosphorus and sodium were predominant in $F$. notialis with respective mean values of $375.44 \pm 0.01$ and $398.38 \pm 0.61 \mathrm{mg} / 100 \mathrm{~g}$. Both sodium and potassium contents in the present study were higher than those: $55.53 \pm 20.97 \mathrm{mg} / 100 \mathrm{~g}$ of sodium and $33.33 \pm 1.76 \mathrm{mg} / 100 \mathrm{~g}$ of potassium, reported for Tympanotonus fuscatus var radula from Abule-Eledu Creek (Moruf and Akinjogunla, 2018). Sodium and potassium are essential in the regulation of $\mathrm{pH}$, osmotic pressure, acid- base equilibrium, muscle and nerve irritability, control glucose absorption, and active transport of glucose/amino acids. In the boiled shellfish samples, investigated minerals were generally found at lower levels when compared with the raw mineral contents. As regards the maximum contents, the highest values of calcium $(323.26 \pm 2.85 \mathrm{mg} / 100 \mathrm{~g})$, magnesium $(304.28 \pm 1.92 \mathrm{mg} / 100 \mathrm{~g})$ and potassium $(86.94 \pm 3.18 \mathrm{mg} / 100 \mathrm{~g})$ were found in $S$. officinalis, while the highest level of phosphorus $(227.97 \pm 3.55 \mathrm{mg} / 100 \mathrm{~g})$ and sodium (135.92 $\pm 0.61 \mathrm{mg} / 100 \mathrm{~g})$ were found in $P$. regius and $F$. notialis respectively. The high content of calcium in $S$. officinalis suggests that its consumption can increase the calcium in the body better than the consumption of $P$. regius and $F$. notialis. However, considering their WHO Daily Value recommendation, these shellfish species are good sources of minerals. In the work of Lawal-Are et al. (2018b), raw sample of the cuttlefish recorded the highest values for all the measured minerals while boiled sample recorded the lowest with the exception of calcium which lowest value was observed in fried sample. Differences found in the shellfish mineral levels could be due to the different physiological state, abiotic factors, biotic factors and processing methods.

Table 4: Mineral content in raw flesh of three imported shellfish species in Nigeria

\begin{tabular}{cccc}
\hline Parameters $(\mathrm{mg} / 100 \mathrm{~g})$ & Sepia officinalis & Palinurus regius & Farfantepenaeus notialis \\
\hline Calcium & $334.2 \pm 3.99^{\mathrm{a}}$ & $106.18 \pm 0.01^{\mathrm{b}}$ & $111.08 \pm 2.69^{\mathrm{b}}$ \\
& $(329.82-342.16)$ & $(106.17-106.19)$ & $(107.07-116.19)$ \\
Magnesium & $363.84 \pm 4.22^{\mathrm{a}}$ & $103.32 \pm 0.01^{\mathrm{b}}$ & $106.37 \pm 2.24^{\mathrm{b}}$ \\
& $(355.46-368.81)$ & $(103.31-103.33)$ & $(103.16-110.69)$ \\
Potassium & $122.62 \pm 0.93^{\mathrm{a}}$ & $305.43 \pm 27.97^{\mathrm{b}}$ & $321.86 \pm 0.12^{\mathrm{b}}$ \\
& $(121.32-124.42)$ & $(249.51-334.65)$ & $(321.74-322.09)$ \\
Phosphorus & $105.67 \pm 5.74^{\mathrm{a}}$ & $257.37 \pm 29.69^{\mathrm{b}}$ & $375.44 \pm 0.01^{\mathrm{c}}$ \\
& $(95.75-115.63)$ & $(201.60-302.92)$ & $(375.43-375.46)$ \\
Sodium & $211.70 \pm 19.79^{\mathrm{a}}$ & $482.15 \pm 2.93^{\mathrm{b}}$ & $398.38 \pm 0.61^{\mathrm{c}}$ \\
& $(175.33-243.41)$ & $(476.53-486.37)$ & $(397.38-399.48)$
\end{tabular}

Keys: Mean \pm SE (Range), Means followed by different letters in the same column differ significantly $(\mathrm{p}<0.05)$ 
Weight yield factor, chemical composition and energy value in three imported shellfish species

Table 5: Mineral content in boiled flesh of three imported shellfish species in Nigeria

\begin{tabular}{llll}
\hline Parameters $(\mathrm{mg} / 100 \mathrm{~g})$ & Sepia officinalis & Palinurus regius & Farfantepenaeus notialis \\
\hline \multirow{2}{*}{ Calcium } & $323.26 \pm 2.85^{\mathrm{a}}$ & $62.66 \pm 53.86^{\mathrm{b}}$ & $14.17 \pm 2.69^{\mathrm{c}}$ \\
& $(319.82-328.91)$ & $(51.89-69.21)$ & $(10.16-19.28)$ \\
Magnesium & $304.28 \pm 1.92^{\mathrm{a}}$ & $46.9 \pm 1.60^{\mathrm{b}}$ & $62.47 \pm 2.24^{\mathrm{c}}$ \\
& $(300.50-306.74)$ & $(43.77-49.02)$ & $(59.26-66.79)$ \\
Potassium & $86.94 \pm 3.18^{\mathrm{a}}$ & $50.35 \pm 1.06^{\mathrm{b}}$ & $46.83 \pm 0.12^{\mathrm{c}}$ \\
& $(82.15-92.95)$ & $(48.24-51.45)$ & $(46.71-47.06)$ \\
Phosphorus & $88.11 \pm 3.00^{\mathrm{a}}$ & $227.97 \pm 3.55^{\mathrm{b}}$ & $188.02 \pm 0.01^{\mathrm{c}}$ \\
\multirow{2}{*}{ Sodium } & $(85.11-94.11)$ & $(221.25-233.29)$ & $(188.01-188.04)$ \\
& $77.17 \pm 12.31^{\mathrm{a}}$ & $90.56 \pm 27.97^{\mathrm{ab}}$ & $135.92 \pm 0.61^{\mathrm{b}}$ \\
& $(54.73-97.14)$ & $(34.64-119.78)$ & $(134.92-137.02)$ \\
\hline
\end{tabular}

Keys: Mean \pm SE (Range), Means followed by different letters in the same column differ significantly $(\mathrm{p}<0.05)$

Energy values of the edible part of imported shellfish species

The total energy (TE) as contributed by the proportion of total energy due to protein (PEP), proportion of total energy due to carbohydrate (PEC) and proportion of total energy due to fat (PEF) in raw and boiled imported shellfish species are shown in Figure 1 and Figure 2 respectively. In raw samples, $S$. officinalis had the highest TE (344.94 kJ 100/g) as contributed by PEP $(216.81 \mathrm{~kJ} 100 / \mathrm{g})>\operatorname{PEF}(76.96 \mathrm{~kJ} \mathrm{100/g})>$ PEC (51.17 kJ 100/g). Same trend follows in the proportion of energy contribution in $P$. regius and F. notialis. This shows that the protein concentration in the flesh of these imported shellfish species in terms of energy would be more than enough to prevent protein energy malnutrition in children and adults fed solely on the shellfish as main sources of protein. In boiled shellfish species, the trend of energy contributions follows decreasing order of PEP $>$ PEF $>$ PEC with the highest energy

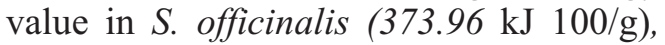
followed by $P$. regius $(341.85 \mathrm{~kJ} 100 / \mathrm{g})$ while the lowest in F. notialis $(340.97 \mathrm{~kJ}$ $100 / \mathrm{g})$. These values did not differ statistically among the shellfish species $(\mathrm{p}<0.05)$. As reported by Adeyeye and Olaleye (2016), an increase in calories from carbohydrate causes hydration; whereas an increase in calories from proteins causes dehydration. Hence, the energy values found in these imported shellfish species were better than those noted for beef jerky meat $(1,659 \mathrm{~kJ} 100 / \mathrm{g})$ (Adeyeye et al., 2020).

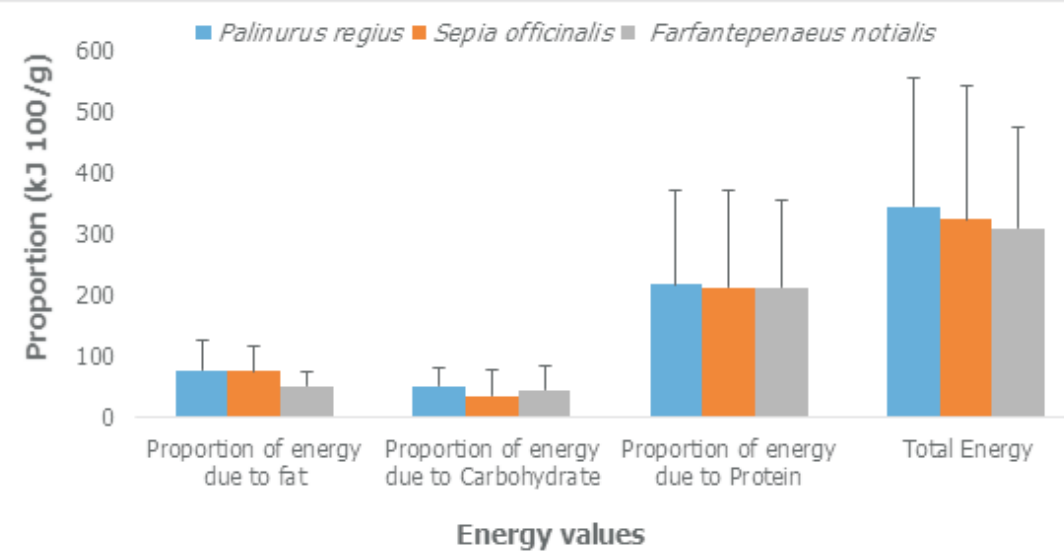

Figure 1: Energy values in raw flesh of three imported shellfish species in Nigeria 68 
Lawal-Are, Moruf, Ojeah, Taiwo and Aligbeh

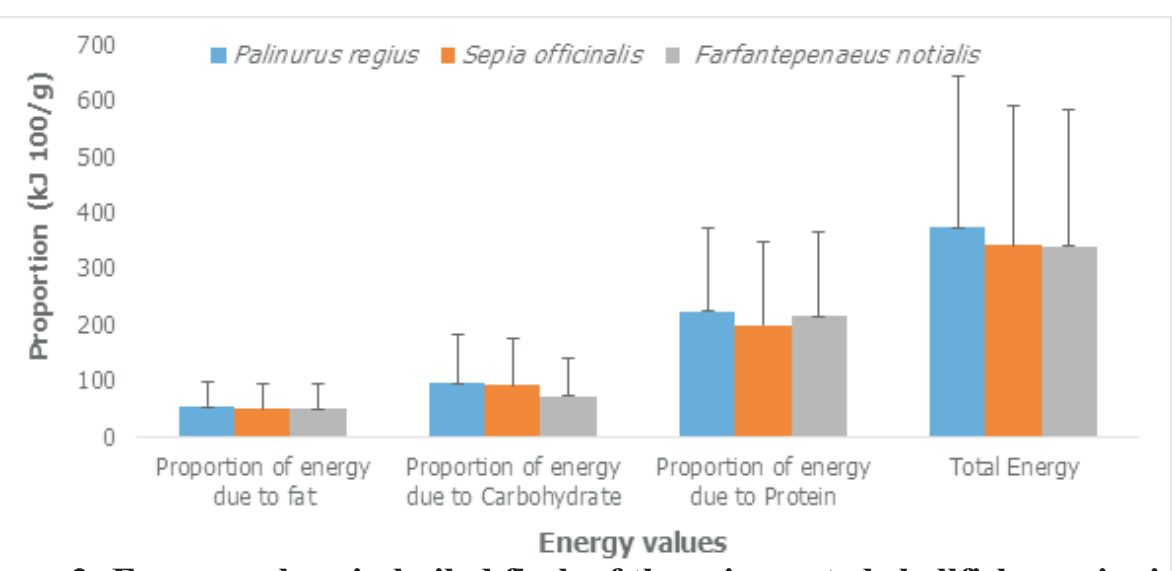

Figure 2: Energy values in boiled flesh of three imported shellfish species in Nigeria

\section{Conclusion}

Despite the differences found for the weight values before as well as after cooking, all the studied imported shellfish species showed weight yield factor less than 1, which is a good commercial quality indicator for edibility. All the species (especially Sepia officinalis) can be considered as food items with interesting dietetic properties due to high contents of proteins, minerals and useful energy values.

\section{References}

AOAC 2006. Official Methods of Analysis, 18th ed., Association of Official Analytical Chemists, Washington, DC

Adeyeye, E. I., Adesina, A. J., Olaleye, A. A., Olagboye, S. A. and Olatunya, M. A. 2020. Proximate, vitamins, minerals compositions together with mineral ratios and mineral safety index of Kilishi (Beef Jerky Meat). Haya: The Saudi Journal of Life Sciences, 5(5): 79-89.

Adeyeye, E. I. and Olaleye, A. A. 2016. Chemical composition and mineral safety index of five insects commonly eaten in South West Nigeria. FUW Trends Sci. Technol. $J ., 1: 139-144$.

Biandolino, F., Di Leo, A., Parlapiano, I.,
Papa, L., Giandomenico, S., Spada, L. and Prato, E. 2019. Nutritional quality of edible marine bivalves from the southern coast of Italy, Mediterranean Sea. Polish Journal of Food and Nutrition Sciences, 69(1): 71-81.

Daniels, A., Gutiérrez, M., Fanjul, G., Guereña, A., Matheson, I. and Watkins, K. 2016. Western Africa's missing fish. The impacts of unreported and unregulated fishing and under-reporting catches by foreign fleets. London: Overseas Development Institute. $45 \mathrm{pp}$.

de Carvalho, L. R. S., da Silva, C. H. D. and Giada, M. D. L. R. 2018. Physical, chemical and sensorial properties of low fat and glutenfree chicken nuggets. Journal of culinary science \& technology, 16(1): 18-29.

Dima, J. B., Baron, P. and Zaritzky, N. 2016. Pasteurization conditions and evaluation of quality parameters of frozen packaged crabmeat. Journal of Aquatic Food Product Technology, 25(5): 745759.

Grunert, K. G., Wills, J., Celemin, L. F., Lahteenmaki, L., Scholderer, J. and Bonsmann, S. S. 2012. Socio- 
Weight yield factor, chemical composition and energy value in three imported shellfish species

demographic and attitudinal determinants of nutrition knowledge of food shoppers in six European countries. Food Quality and Preference, 26: 166-177.

Lawal-Are, A. O., Moruf, R. O. and Afolayan, O. A. 2018a. Proximate composition, mineral profile and cholesterol level in whole and fillet of the Guinean Mantis Shrimp, Squilla aculeata calmani (Holthuis, 1959) (Crustacea: Stomatopoda). Albanian Journal of Agricultural Sciences, 17(3): 160-165.

Lawal-Are, A. O., Moruf, R. O., Junaid, D. A. and Oke, M. O. $2018 b$. Chemical bio-compounds and functional properties of raw and processed cuttlefish, Sepia officinalis (Mollus ca: Cephalopoda). Food and Environmental Safety, 17(3): 332 340.

Merrill, A. L. and Watt, B. K. 1955. Energy values of food. Basis and derivation. Washington, DC: US Department of Agriculture Handbook.

Moruf, H. A., Ogunbambo, M. M. and Moruf, R. O. 2020. The relevance of information of shellfish quality on consumers' purchase decision in Lagos metropolis, Nigeria. Journal of Agricultural Economics, Environment and Social Sciences, 6(1): $71-79$.

Moruf, R. O. 2020. Sustainability in life below water: Managing the exploitation of Nigerian shellfish resources. Proceedings of the Nigerian Academy of Science, 13(1): 126-135.

Moruf, R. O. and Adekoya, K. O. 2018. Molluscan and crustacean genetic and biotechnology interventions: A review. Animal Research International, 15(1): 2906-2917.
Moruf, R. O. and Akinjogunla, V. F. 2018. Photometric determination of macro-micro minerals in the West African Mud Creeper, Tympanotonus fuscatus var radula (Linnaeus, 1758). Journal of Experimental Research, 6(3): 3540.

Moruf, R. O. and Lawal-Are, A. O. 2019. Protein, amino acid and fatty acid profiles of two edible crabs of Lagos coast, Nigeria. Journal of Bangladesh Agricultural University, 17(3): 396-401.

Moruf, R. O, Saba, A. O., ChukwuOsazuwa, J. and Elegbede, I. $O$. 2019. Seasonal variation in MacroMicronutrient compositions of the flesh and shell of the Portunid Crab, Callinectes amnicola (De Rochebrune, 1883) from the coastal waters of Southwest Nigeria. Agricultura, 102 (1-2): 200-209.

Norhana, W., Nor Ainy, M., Othman, M., Faazaz, A. L., Ismail, I. and Yusri, A. 2011. Establishment of a shellfish model farm: a case study in Sg. Jarum Mas, Perak, Malaysia. International Food Research Journal, 18(1): 79-94.

Ojagh, S. M., Shabanpour, B. and Jamshidi, A. 2013. The effect of different pre-fried temperatures on physical and chemical characteristics of silver carp fish (Hypophthalmichthys molitrix) nuggets. World Journal of Fish and Marine Sciences, 5(4): 414-420.

Santoso, J., Yoshie-Stark, Y. and Suzuki, T. 2006. Comparative content of minerals and dietary fibers in several tropical seaweeds. Bull. Aquatic Products Technol., 9 (1): $1-11$.

Zhukova, N. V. 2014. Lipids and fatty acids of Nudibranch Mollusks: Potential sources of bioactive compounds. Marine Drugs, 12(8): 4578-4592.

Received: $16^{\text {th }}$ October, 2020 Accepted: $18^{\text {th }}$ February, 2021 